\begin{tabular}{|c|c|c|}
\hline \multirow[b]{2}{*}{ II EST } & Int.J.Curr.Microbiol.App.Sci (2021) 10(09): 152-162 & \\
\hline & $\begin{array}{l}\text { International Journal of Current Microbiology and Applied Sciences } \\
\text { ISSN: 2319-7706 Volume } 10 \text { Number } 09 \text { (2021) } \\
\text { Journal homepage: } \underline{\text { http://www.ijcmas.com }}\end{array}$ & 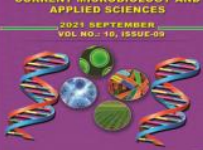 \\
\hline PUBLISHERS & & www.ijemas.com \\
\hline
\end{tabular}

\title{
Evaluation of Botanicals of Invasive Plant Species and Fungicides against Fungal Pathogens of Forest Nursery
}

\author{
Ranjana Juwantha', Akshit K. Lohan², Mohit Singh Bisht', \\ Jalaj Saxena $^{1 *}$ and Pooja Kapoor ${ }^{1}$ \\ ${ }^{1}$ Forest Pathology Discipline, Forest Protection Division, Forest Research Institute, \\ Dehradun, India \\ ${ }^{2}$ The Oxford College of Science, Bangalore University, Bengaluru, Karnataka, India \\ *Corresponding author
}

A B S T R A C T

Keywords

Botanical

Fungicide;

Antifungal Activity;

Fungal Pathogens;

Invasive Plant

Species

Article Info

Accepted:

10 August 2021

Available Online:

10 September 2021
Investigation of plants that possess natural antimicrobial substances for plant protection has been recognized as a promising disease management strategy. Alternaria alternata, Fusarium solani, Macrophomina sp. and Pestalotiopsis sp. isolated from diverse hosts such as Azadirachta indica, Melia dubia, Saraca indica and Quercus leucotrichophora produce important diseases in forest nurseries such as leaf blight, leaf spot, and wilt. In this study, botanicals from two invasive plant species, Ageratina adenophora and Ageratum conyzoides, were prepared and tested against plant diseases. Two botanicals (Methanolic extract obtained from the leaves of these two invasive species) and two fungicides were evaluated for their fungal growth inhibitory effects. At 1.5 percent concentration, the methanolic extract of Ageratina adenophora was found highly effective, inhibiting the growth of Macrophomina sp., (71.94\%) followed by Pestalotiopsis sp. (70.20\%), Alternaria alternata (51.92\%) and Fusarium solani (47.03\%). Whereas, Systemic chemical fungicide Thiophanate methylat $1.5 \%$ concentration showed maximum mycelial growth inhibition of Alternaria alternata (77.20\%) and Macrophomina sp. (82.43\%) and being deadlier to Pestalotiopsis sp. (100\%) and Fusarium solani (100\%). Their comparative analysis showed that higher doses of Ageratina adenophora caused either more or almost equal pathogen growth inhibition than lower doses of Chlorothalonil for certain fungi. Thus, promoting eco-friendly disease management strategies such as botanical control would be beneficial in reducing the need for pesticides.

\section{Introduction}

Developing countries often face heavy yield losses due to lack of capacity to manage diseases, leading to shortage of adequate food supplies (Klauser et al., 2018; Strange and Scott, 2005). Plant diseases are usually caused by pathogens such as fungi, bacteria, 
nematodes, and viruses. However, fungi cause the widest range of diseases in various tree hosts, resulting in the biggest impact. The most commonly implied chemical fungicides are hazardous and may have detrimental effect on the surrounding environment and organisms. Some of them, such as halogenated hydrocarbons like methyl bromide, are even known to deplete the ozone layer (Abritton and Watson, 1992). Chemical fungicides' negative impacts on the environment and human health have spurred researchers to look for safer alternatives, which has sparked research and development of bio-pesticides, including botanical fungicides. Generally, biopesticides are categorized as natural products (plant-derived, animal-derived, and microorganism-derived) and microorganisms (Yoon et al., 2013). Many plant species contain antifungal compounds (Hostettmann et al., 2000).

Invasive plant species are aggressive colonizers and their successful invasion is an outcome of many morphological, physiological, and ecological features. If an invasive species contains good antifungal activity, it may be a useful source of antifungal compounds or extracts (Mdee et al., 2009) thereby, positively impacting the management of these invasive weed species.

Ageratina adenophora and Ageratum conyzoides are the two invasive weed species being studied here for their antifungal activity compared to chemical fungicides. Ageratina adenophora (Spreng.) R. M. King and H. Rob. syn. Eupatorium adenophorum (Asteraceae), commonly known as Crofton weed, is an endemic plant species of Central America (mainly Mexico). It has invaded more than 30 countries, including India, Thailand, New Zealand, Australia, America and China (Liu et al., 2006; Li and Feng, 2009). Ageratum conyzoides (L.) L. (Asteraceae), commonly known as Billy Goat weed, is an aggressive invasive weed of agricultural fields that causes yield reductions of major staple crops in India (Kohli et al., 2006). When it invades rangeland areas, it competes with native grasses, causing scarcity of fodder. Despite its obnoxious nature and bad economic and environmental consequences, A. adenophorais reported to have medicinal properties, and its uses in folk medicine as an antimicrobial, analgesic, antipyretic, antiseptic, blood coagulant and enhancer of phenobarbitone induced sleep, etc. have also been reported (Mandal et al., 1981; Ansari et al., 1983; Rai and Sharma 1994). Invasive weeds have a variety of adverse effects on ecological and human health, thus their usage as a source of botanical fungicides has a higher value in terms of management and value addition.

The present study investigates antifungal activities of botanicals derived from invasive species compared to traditionally used systemic and non-systemic fungicides against foliar and root rot pathogens such as Alternaria alternata (Mehrotra and Pandey 1992), Fusarium solani (Pandey et al., 2018), Pestalotiopsis sp. (Ramakrishnan and Subramanian 1952; Dube and Bilgrami, 1999)., Macrophomina sp. (Prakash et al., 2007), and Phomopsis sp. (Chowdhury 1966; Sahni 1968) that cause leaf blight, leaf spot, and wilt in Quercus leucotrichophora (Oak), Azadirachta indica (Neem), Melia dubia (Malabar neem) and Saraca indica (Ashok). This study will be useful for researchers and farmers to employ the selected effective botanical fungicides in the field condition to effectively manage the disease by including eco-friendly treatments such as bio-agents.

\section{Materials and Methods}

The methodology for screening different botanicals and chemical fungicides for the selected fungal pathogens was finalized referring to different techniques by Dhingra and Sinclair (1995). The details of the 
materials and methods employed were as below:

Isolation and identification of phytopathogens

Infected leaf, stem, and root samples of Melia, Oak, and Neem were collected from the Forest Research Institute's Central Nursery in Dehradun to isolate pathogens using a moist chamber (Petrini and Fisher, 1886) and a surface sterilization technique (Milovanović et al., 2009). Pathogen cultures were then isolated, purified using the single spore isolation method, and maintained on potato dextrose agar slants and stored in a refrigerator at $4^{\circ} \mathrm{C}$. Their Characterization was based on macroscopic and microscopic characters, viz. Alternaria alternata, Fusarium solani, Pestalotiopsis sp., and Macrophomina sp. using standard identification keys (Barnett 1972; Booth 1971).

\section{Preparation of botanicals}

Leaves from two invasive plant species, Ageratina adenophora and Ageratum conyzoides, were used to make two distinct botanicals (methanolic extract) for in-vitro investigations. Formethanolic extraction, the leaves were ground in a mixer grinder to get a smooth powder. This powder was then subjected to sonication as given by Nene and Thapliyal (1993).

\section{In vitro evaluation of botanicals}

The poisoned food technique (Nene and Thapliyal 1979) was used to investigate the antifungal efficacy of plant extracts. PDA growing medium was combined with different concentrations of extracts $(0.5 \%, 1 \%$, and $1.5 \%$ ). With a sterile cork borer of $5 \mathrm{~mm}$, an agar plug containing pathogen mycelium from a seven-day old culture was sliced and aseptically put in the center of each petri dish using a sterile needle. The Petri plates without extracts in the PDA medium served as control. Then, the Petri plates were incubated at $25 \pm 1^{\circ} \mathrm{C}$ for 7 days, after which radial growth of mycelium was measured and percent inhibition was calculated by the Vincent (1947) formula:

$\mathrm{I} \%=[(\mathrm{C}-\mathrm{T}) / \mathrm{C})] \mathrm{x} 100$

Where,

$\mathrm{I}=$ inhibition percent of mycelium

$\mathrm{C}=$ Colony diameter in the control $(\mathrm{cm})$

$\mathrm{T}=$ Colony diameter in treated $(\mathrm{cm})$

\section{In-vitro evaluation of fungicide}

The efficacy of systemic (Thiophanate methyl) and non-systemic (Chlorothalonil) was tested at concentrations of $0.5 \%, 0.75 \%$, and $1 \%$.

The active ingredient concentration was calculated to evaluate the fungicide, which was then compared to the impact of botanicals on pathogenic fungus. The above mentioned Vincent, 1947 formula was used to evaluate inhibition percentage.

\section{Results and Discussion}

Effect of different botanicals and fungicides on colony growth of fungal pathogens.

Laboratory evaluation of botanicals and fungicides revealed that both the agents caused various inhibitions of forest pathogenic fungi at various concentrations (Table 1 and 2).

\section{In-vitro evaluation of botanicals}

Pathogens showed differential growth patterns in different botanical concentrations. Table 1 depicted the pattern of growth and inhibition 
of Alternaria alternata, Fusarium solani, Pestalotiopsis sp., and Macrophomina sp. at different botanical concentrations $(0.5 \%, 1 \%$ and $1.5 \%$ ). It was found that all fungi exhibited good growth only at lower concentrations of botanical fungicides tested, i.e., $0.5 \%$ and $1 \%$. While complete or intense growth inhibition was recorded at higher concentrations of botanical fungicides $(1.5 \%)$ (Figure.1). Therefore, a decrease in colony growth is directly associated with an increase in the concentration of botanicals.

In the case of Alternaria alternata, Ageratina adenophora $(1.5 \%)$ caused maximum inhibition (51.92\%), followed by Ageratum conyzoides $1.5 \%(30.8 \%)$, Ageratina adenophora $1 \%(22.6 \%)$ and Ageratum conyzoides $1 \% \quad(16.6 \%)$ etc. Ageratina adenophora was found to be more effective against Alternaria alternata as compared to Ageratum conyzoides.

Botanical fungicides from Ageratina adenophora $1.5 \%$ caused maximum inhibition of Fusarium solani (47.03\%), followed by Ageratina adenophora 1\% (43.44\%), Ageratina adenophora $0.5 \%(40.39 \%)$ and Ageratum conyzoides $1.5 \% \quad(30.69 \%)$ etc. Ageratina adenophora was found to be more effective against Fusarium solani as compared to Ageratum conyzoides. Ageratina adenophora $1.5 \%$ caused maximum inhibition against Macrophomina sp. (71.94\%), followed by Ageratina adenophora $1 \%(66 \%)$, Ageratina adenophora $0.5 \%(60.21 \%)$ and Ageratum conyzoides $1.5 \%(46.49 \%)$ etc. Ageratina adenophora was found to be more effective against Macrophomina sp. as compared to Ageratum conyzoides.

Pestalotiopsis sp. was maximum inhibited by Ageratina adenophora $1.5 \%$ (70.2\%), followed by Ageratum conyzoides $1.5 \%$ (60\%), Ageratina adenophora 1\% (51.21\%) and Ageratum conyzoides $1 \% \quad(42 \%)$ etc.
Ageratina adenophora was found to be more effective against Pestalotiopsis sp. as compared to Ageratum conyzoides.

Although Methanolic extract of Ageratina adenophora showed greater efficacy in controlling all pathogens growth, Ageratina adenophora and Ageratum conyzoides both can be used as potential candidates for inhibiting pathogen's growth.

\section{In-vitro evaluation of fungicides}

Systemic (Thiophanate methyl) and nonsystemic (Chlorothalonil) fungicides were tested at three different concentrations in the laboratory for their efficacy against different pathogens and used for comparative study against botanicals' effect on pathogens.

Table 2 states that all the pathogens tend to exhibit growth inhibition at lower concentrations of chemical fungicides tested.

It was noticed that Fusarium solani and Pestalotiopsis $\mathrm{sp}$. showed no growth even at slightly higher concentrations of fungicides i.e. $1 \%$ and $1.5 \%$ (Figure 2).

Lower doses of thiophanate methyl are equally effective as higher doses of chlorothalonil. Therefore, its higher doses can be lethal to plant growth-promoting microbes in the soil.

In the case of Alternaria alternata, Thiophanate methyl $1.5 \%$ caused maximum growth inhibition i.e (77.20\%) followed by Thiophanate methyl1\% (75.12\%), Thiophanate methyl $0.5 \% \quad(73.05 \%)$, Chlorothalonil $1.5 \%(58.03 \%)$ etc. Fusarium solani showed complete growth inhibition $(100 \%)$ through Thiophanate methyl $1.5 \%$ and $1 \%$ followed by Thiophanate methyl $0.5 \%$ (75.58\%), Chlorothalonil 1.5\% (54.65\%) etc. 
Table.1 Effect of different concentration of Ageratina adenophora and Ageratum conyzoides leaf extracts on vegetative growth of pathogens

\begin{tabular}{|c|c|c|c|c|c|c|c|c|c|c|c|}
\hline \multirow[t]{2}{*}{ Isolates } & \multirow[t]{2}{*}{ Botanicals } & \multicolumn{4}{|c|}{$\begin{array}{c}\text { Botanical concentration \%/ } \\
\text { Average mycelia Growth ( } \mathbf{m m})\end{array}$} & \multirow[t]{2}{*}{ Mean } & \multicolumn{4}{|c|}{$\begin{array}{c}\text { Botanical concentration }(\%) / \\
\text { Average mycelia growth } \\
\text { Inhibition }(\%)\end{array}$} & \multirow[t]{2}{*}{ Mean } \\
\hline & & Control & $0.50 \%$ & $1 \%$ & $1.5 \%$ & & Control & $0.50 \%$ & $1 \%$ & $1.5 \%$ & \\
\hline \multirow[t]{2}{*}{ Alternaria alternata } & Ageratina adenophora & 44.2 & 38.5 & 34.2 & 21.25 & 31.32 & 0.00 & 12.89 & 22.6 & 51.92 & 29.14 \\
\hline & Ageratum conyzoides & 49.5 & 44 & 41.25 & 34.25 & 39.89 & 0.00 & 11.11 & 16.6 & 30.8 & 19.25 \\
\hline \multirow[t]{2}{*}{ Fusarium solani } & Ageratina adenophora & 55.7 & 33.2 & 31.5 & 29.5 & 31.4 & 0.00 & 40.39 & 43.44 & 47.03 & 43.62 \\
\hline & Ageratum conyzoides & 50.5 & 44 & 43.75 & 35.25 & 41 & 0.00 & 12.87 & 13.36 & 30.69 & 18.97 \\
\hline \multirow[t]{2}{*}{ Macrophomina sp. } & Ageratina adenophora & 59.7 & 23.75 & 20 & 16.75 & 20.17 & 0.00 & 60.21 & 66 & 71.94 & 66.05 \\
\hline & Ageratum conyzoides & 54.25 & 41.75 & 40.75 & 29 & 37.16 & 0.00 & 23.06 & 24.9 & 46.49 & 31.48 \\
\hline \multirow[t]{2}{*}{ Pestalotiopsis sp. } & Ageratina adenophora & 53.7 & 32.5 & 26.2 & 16 & 24.9 & 0.00 & 39.47 & 51.21 & 70.20 & 53.63 \\
\hline & Ageratum conyzoides & 50 & 47.25 & 29 & 20 & 32.08 & 0.00 & 12 & 42 & 60 & 38 \\
\hline \multirow[t]{2}{*}{ Mean } & Ageratina adenophora & & 31.99 & 27.9 & 20.87 & & & 38.24 & 45.81 & 60.27 & \\
\hline & Ageratum conyzoides & & 44.25 & 38.69 & 29.62 & & & 14.76 & 24.23 & 41.99 & \\
\hline
\end{tabular}


Table.2 Effect of different concentrations of thiophanate methyl and chlorothalonil on vegetative growth of pathogens

\begin{tabular}{|c|c|c|c|c|c|c|c|c|c|c|c|}
\hline \multirow[t]{2}{*}{ Isolates } & \multirow[t]{2}{*}{ Botanicals } & \multicolumn{4}{|c|}{$\begin{array}{c}\text { Botanical concentration \%/ } \\
\text { Average mycelia Growth (mm) }\end{array}$} & \multirow[t]{2}{*}{ Mean } & \multicolumn{4}{|c|}{$\begin{array}{c}\text { Botanical concentration }(\%) / \\
\text { Average mycelia growth } \\
\text { Inhibition }(\%)\end{array}$} & \multirow[t]{2}{*}{ Mean } \\
\hline & & Control & $0.50 \%$ & $1 \%$ & $1.5 \%$ & & Control & $0.50 \%$ & $1 \%$ & $1.5 \%$ & \\
\hline \multirow[t]{2}{*}{ Alternaria alternata } & $\begin{array}{c}\text { Thiophanate } \\
\text { methyl }\end{array}$ & 48.25 & 13.1 & 12 & 11 & 12.03 & 0.00 & 73.05 & 75.12 & 77.20 & 75.12 \\
\hline & Chlorothalonil & & 22 & 21.25 & 20.25 & 21.17 & 0.00 & 54.4 & 55.95 & 58.03 & 56.13 \\
\hline \multirow[t]{2}{*}{ Fusarium solani } & $\begin{array}{c}\text { Thiophanate } \\
\text { methyl }\end{array}$ & 43 & 10.5 & 0.00 & 0.00 & 3.5 & 0.00 & 75.58 & 100 & 100 & 91.86 \\
\hline & Chlorothalonil & & 23.5 & 21 & 19.5 & 21.33 & 0.00 & 45.34 & 51.16 & 54.65 & 50.38 \\
\hline \multirow[t]{2}{*}{ Macrophomina sp. } & $\begin{array}{l}\text { Thiophanate } \\
\text { methyl }\end{array}$ & 63.75 & 12 & 11.5 & 11.25 & 11.58 & 0.00 & 81.17 & 81.96 & 82.43 & 81.85 \\
\hline & Chlorothalonil & & 33.25 & 26 & 24.5 & 27.92 & 0.00 & 47.84 & 59.21 & 61.56 & 56.20 \\
\hline \multirow[t]{2}{*}{ Pestalotiopsis sp. } & $\begin{array}{l}\text { Thiophanate } \\
\text { methyl }\end{array}$ & 43 & 0.00 & 0.00 & 0.00 & 0.00 & 0.00 & 100 & 100 & 100 & 100 \\
\hline & Chlorothalonil & & 20 & 18.5 & 15.5 & 18 & 0.00 & 53.48 & 56.97 & 63.95 & 58.13 \\
\hline \multirow[t]{2}{*}{ Mean } & $\begin{array}{c}\text { Thiophanate } \\
\text { methyl }\end{array}$ & & 8.9 & 5.87 & 5.56 & & & 82.45 & 89.27 & 89.91 & \\
\hline & Chlorothalonil & & 24.69 & 21.69 & 19.94 & & & 50.26 & 55.75 & 59.55 & \\
\hline
\end{tabular}


Fig.1 Effect of different concentrations of botanicals of Ageratina adenophora and Ageratum conyzoides on growth of pathogens

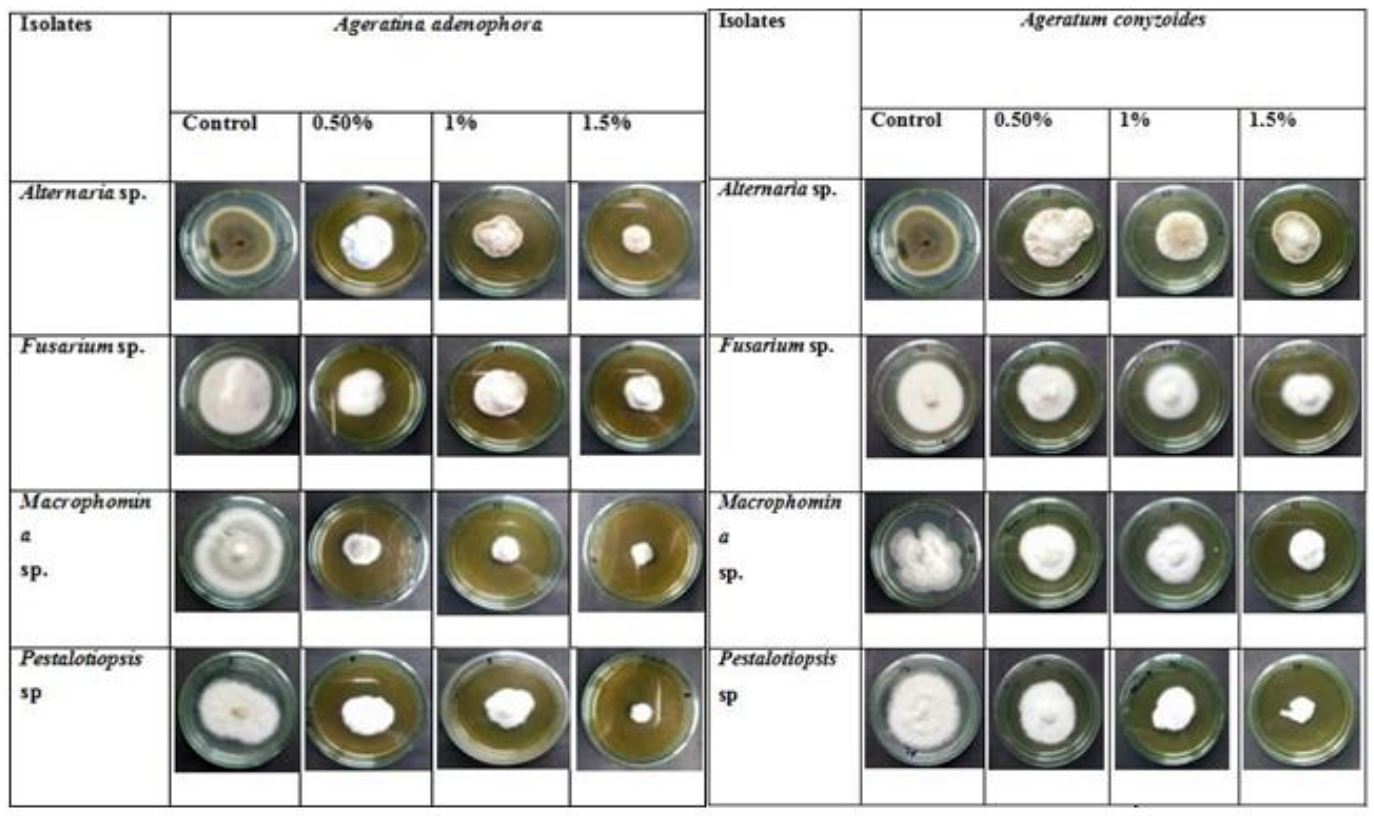

Fig.2 Effect of different concentrations of Thiophanate methyl and Chlorothalonil fungicides on the growth of pathogens

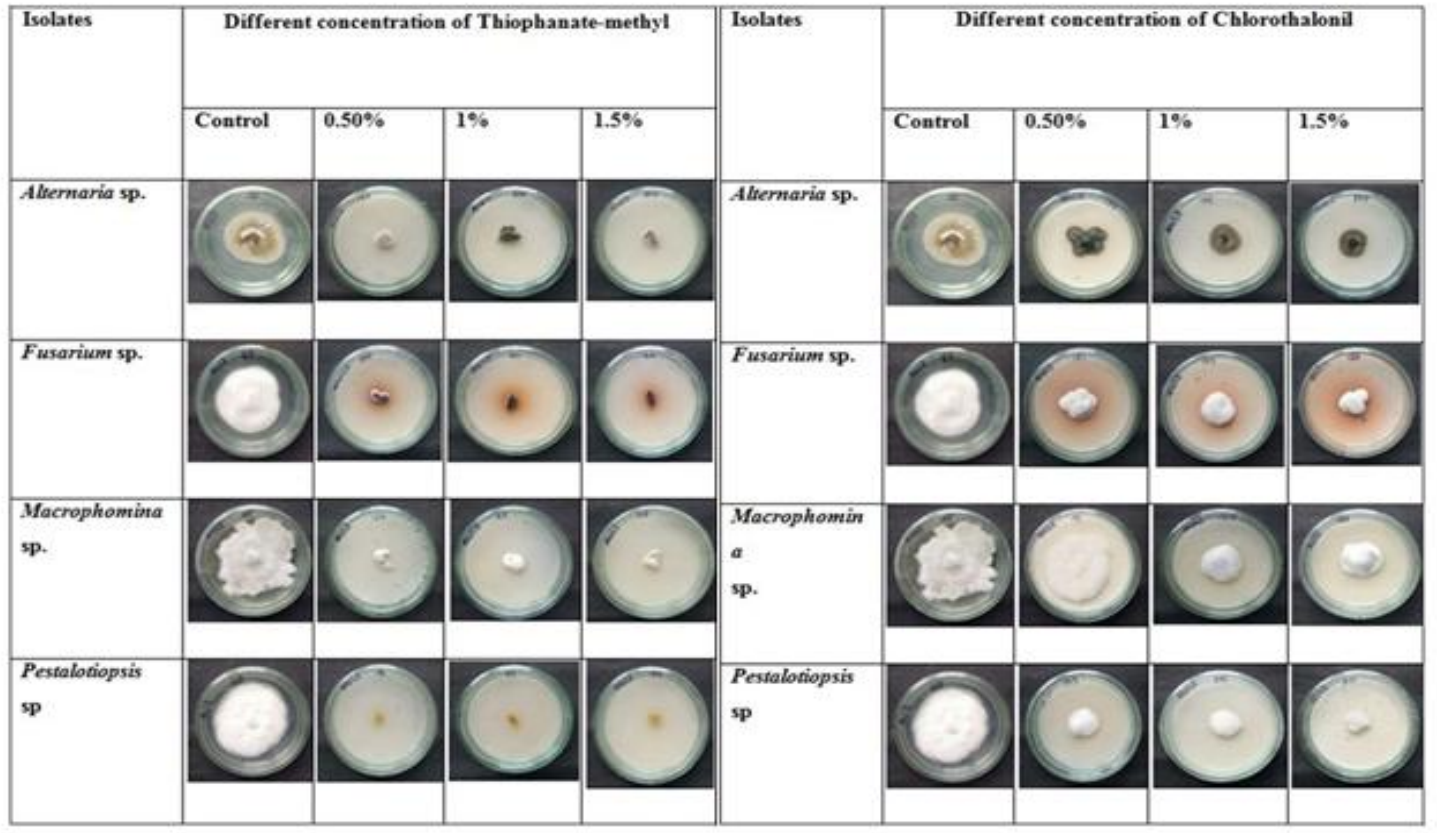


Fig.3
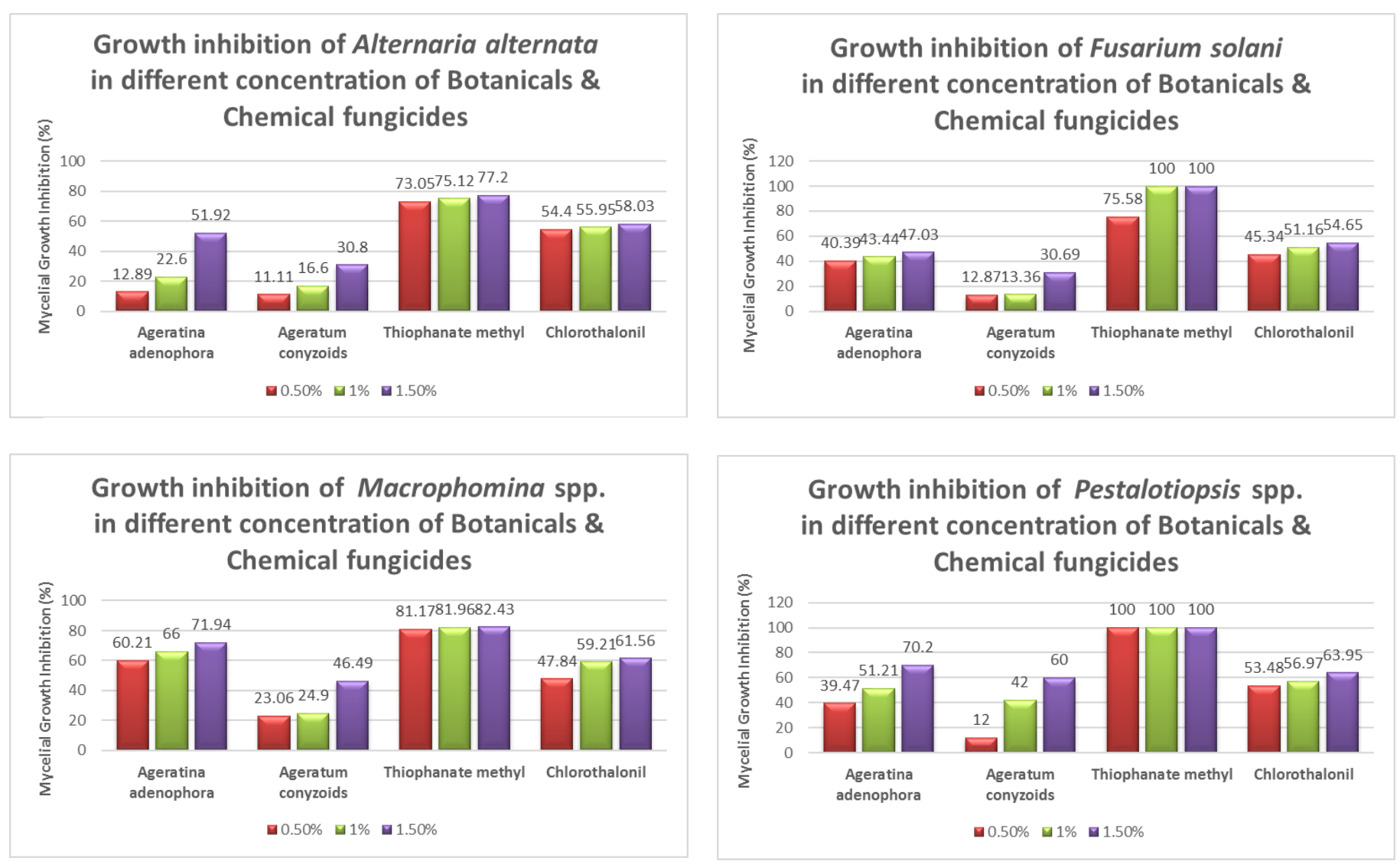

Here, Thiophanate methyl was found to be the most effective, even at a very low concentration of the fungicide. Growth inhibition pattern in Macrophomina sp. Thiophanate methyl $1.5 \% \quad(82.43 \%)$, Thiophanate methyl $1 \% \quad(81.96 \%)$, Thiophanate methyl $0.5 \% \quad(81.17 \%)$, Chlorothalonil $1.5 \% \quad(61.56 \%)$ etc. For Pestalotiopsis sp., Thiophanate methyl 1.5\% caused maximum inhibition (100\%) followed by Thiophanate methyl1\%(100\%), Thiophanate methyl $0.5 \%$ (100\%), Chlorothalonil $1.5 \%$ (63.95\%) etc. The overall estimate reveals that Thiophanate methyl was the most effective fungicide for controlling the growth of selected pathogens.

\section{Disease inhibition potential among fungicides and botanicals}

to find out the potential of botanicals for disease control against chemical fungicides. The results revealed that Thiophanate methyl and Chlorothalonil had very high efficacy in controlling Alternaria alternata, but a higher concentration of Ageratina adenophora $1.5 \%$ showed almost similar growth inhibition $(51.92 \%)$ as in Chlorothalonil (54.4\%). Fusarium solani showed maximum inhibition (upto $100 \%$ ) by the systemic fungicide Thiophanate methyl. Whereas, in the case of Chlorothalonil and Ageratina adenophora growth pattern was $54.65 \%$ and $47.03 \%$ (1.5\%), $51.16 \%$ and $43.44 \%(1 \%)$ and 45.34 and $40.39(0.5 \%)$ respectively. Macrophomina sp. showed better inhibition (71.94\%) in Ageratina adenophora $1.5 \%$ than in Chlorothalonil $1.5 \%$ (61.56\%). Similarly, Pestalotiopsis sp. showed better inhibition (70.20\%) in Ageratina adenophora $1.5 \%$ than The growth inhibition results were compared in Chlorothalonil 1.5\% (63.95\%). However, 
thiophanate methyl was still the most effective, causing up to $82.43 \%$ in Macrophomina sp. and 100\% in Pestalotiopsis sp. growth inhibition.

Many plants and plant products have been reported to have antimicrobial activities against plant pathogenic fungi (Bashar and Rai, 1992). Invasive species can be utilized for plant disease control as they are rapid colonizers of an ecosystem and have no natural enemies. Their disease resistance capacity may be attributed to their bioactive compounds that hinder pathogen growth. The disease resistance potential of botanicals from some invasive species has also been studied by several workers (Pal et al., 2013; Srivastava and Singh, 2011).

The present study reveals that the methanolic extract of Ageratina adenophora is highly effective against Macrophomina sp., followed by Pestalotiopsis sp., Alternaria alternata and Fusarium solani. Similar trends were observed in earlier studies for inhibiting plant pathogenic fungi growth by botanicals derived from different species (Khatun and Shamsi, 2016; Rai et al., 2000; Deshmukh et al., 2021). Whereas, in the case of fungicides, thiophanate methyl was found to be the most effective, inhibiting maximum growth in Alternaria alternata and Macrophomina sp. and being deadlier to Pestalotiopsis sp. and Fusarium solani. Chase et al., 1993 also observed that thiophanate methylcan control the leaf spot of Dracaena marginata caused by Fusarium. A comparative analysis showed that higher doses of Ageratina adenophora caused either more or almost equal pathogen growth inhibition than lower doses of Chlorothalonil for certain fungi. It is a wellknown fact that chemical fungicides are best suitable for pathogen treatments, but their environmental implications are irreparable. The accumulation of fungicides in the soil negatively affects organisms present in this ecosystem as well as biological processes (Devashree et al., 2014). Chlorothalonil applied to sandy loam and loamy sand soils causes changes in the biological homeostasis of the soil and disturbs the soil microbiota (Baćmaga et al., 2018). Therefore, the use of plant-derived fungicides isa better alternative that is both eco-friendly and economical.

If we compare the effect of chemical fungicides with botanicals on pathogen growth suppression, we find that botanicals are better against the low concentration of some chemical fungicides. Botanicals can be effective in field trials in high concentrations as there is no chance of them being harmful to the plant and soil. That might be a concern with other bio-control agents that can be opportunistic pathogenic. It is clear from the study that botanical fungicides are considerably effective and can be used as an alternative to traditionally used fungicides in controlling the growth of fungal plant pathogens. Thus, the promotion of ecofriendly strategies such as botanical control via invasive weed species would minimize the use of chemicals in disease management and would also be a valuable addition to invasive weed species.

\section{References}

Abritton, D. L., and Watson, R. T. (1992). Methyl bromide interim scientific assessment. Montreal Protocol Assessment Supplementary Report. The United Nations Environmental Program (UNEP), New York.

Ansari, S., Jain, P., Tyagi, R. P., Joshi, B. C., and Barar, F. S. K. (1983). Phytochemical and phamacological studies of the aerial parts of Eupatorium adenophorum L. HerbaPolonica.

Baćmaga, M., Wyszkowska, J., and Kucharski, J. (2018). The influence of chlorothalonil on the activity of soil microorganisms and 
enzymes. Ecotoxicology, 27(9), 11881202.

Barnett, H. L., and Hunter, B. B. (1972). Illustrated genera of imperfect fungi. Illustrated genera of imperfect fungi., (3rd ed).

Bashar, M. A., and RAI, B. (1992). Antifungal property of Clematis gouriana against some pathogenic root infecting fungi of chickpea. Journal of the Indian Botanical Society, 71(1-4), 307-308.

Booth, C. (1971). The genus fusarium. The genus Fusarium.

Chase, A. R. (1993). Efficacy of thiophanate methyl fungicides for diseases of Florida ornamentals. In Florida State Horticultural Society. Meeting (USA).

Chowdhury, S. R. (1970). Notes on fungi occurring at Raipur (Madhya Pradesh). III. Proc Nat AcadSci India Sect B, 40(1), 5256.

Deshmukh, M. M., andVanitha, S. (2021). In vitro Evaluation of Leaf Extracts against Macrophominaphaseolina in Mulberry through Poisoned Food Technique. Research Biotica,3(2), 121123.

Devashree, Y., Dutta, B. K., Paul, S. B., and Choudhury, S. (2014). The effect of paraquat and fipronil on the soil and rhizosphere microflora of tea (Camellia sinensis (L) O. kuntze). International Journal of Innovation and Applied Studies, 7(4), 1534.

Dhingra, O. D., and Sinclair, J. B. (1995). Basic plant pathology methods., 2nd edn.(Lewis Publishers: Boca Raton, FL).

Dube, H. C., and Bilgrami, K. S. (1966). A new species of Pestalotiopsis on the leaves of Rhododendron grande Wight. Indian Phytopathol, 19, 320-321.

Hostettmann, K., Marston, A., Ndjoko, K., and Wolfender, J. L. (2000). The potential of African plants as a source of drugs. Current Organic Chemistry, 4(10), 9731010.

Khatun, A., and Shamsi, S. (2016). In vitro evaluation of fungicides and plant extracts against the fungi associated with seeds of nine chickpea varieties. Dhaka University Journal of Biological Sciences, 25(1), 8390.

Klauser, D. (2018). Challenges in monitoring and managing plant diseases in developing countries. Journal of Plant Diseases and Protection, 125(3), 235-237.

Kohli, R. K., Batish, D. R., Singh, H. P., and Dogra, K. S. (2006). Status, invasiveness and environmental threats of three tropical American invasive weeds (Parthenium hysterophorus L., Ageratum conyzoides L., Lantana camara L.) in India. Biological Invasions, 8(7), 1501-1510.

Li, Y. P., and Feng, Y. L. (2009). Differences in seed morphometric and germination traits of crofton weed (Eupatorium adenophorum) from different elevations. Weed Science, 57(1), 26-30.

Liu, J., Dong, M., Miao, S. L., Li, Z. Y., Song, M. H., and Wang, R. Q. (2006). Invasive alien plants in China: role of clonality and geographical origin. Biological Invasions, 8(7), 1461-1470.

Mandal, S. K., Mandal, S. C., Das, A. K., Tag, H., and Sur, T. (1981). Antipyretic activity of Eupatorium adenophorum leaf extract. Indian J Nat Prod, 21(1), 6-9.

Mdee, L. K., Masoko, P., and Eloff, J. N. (2009). The activity of extracts of seven common invasive plant species on fungal phytopathogens. South African Journal of Botany, 75(2), 375-379.

Mehrotra, M. D., and Pandey, P. C. (1992). Some important nursery diseases of Azadirachta indica and their control. Monograph of Neem.

Milovanović, I. L., Mišan, A. Č., Sakač, M. B., Čabarkapa, I. S., Šarić, B. M., Matić, J. J., and Jovanov, P. T. (2009). Evaluation of a GC-MS method for the analysis of oregano essential oil composition. Food Processing, Quality and Safety, 36(3-4), 75-89.

Nene, Y. L. and Thapliyal, P. N. (1993). Fungicides in plant disease control, 3rd edition. Oxford and IBH Publishing Co. Pvt. Ltd., New Delhi. pp. 526-531. 
Nene, Y. L., and Thapliyal, P. N. (1979). Fungicides in plant disease control. Fungicides in plant disease control., (Ed. 2).

Pal, G. K., Kumar, B., and Shahi, S. K. (2013). Antifungal activity of some common weed extracts against phytopathogenic fungi Alternaria sp. International journal of universal pharmacy and life sciences, 3(2), 6-14.

Pandey, A., Juwantha, R., Chandra, S., Kumar, A., Kannojia, P., Khanna, D., and Pandey, S. (2018). First report of Fusarium solani causing wilt of Melia dubia. Forest pathology, 48(1), e12398.

Petrini, O., and Fisher, P. J. (1986). Fungal endophytes in Salicornia perennis. Transactions of the British Mycological Society, 87(4), 647-651.

Prakash, V. R., Venugopal, S., and Thomas, S. (2007). First report of macrophomina leaf spot (Macrophomina phaseolina) on Artocarpus hirsutus in India. Plant Archives, 7(2), 929-930.

Rai, L., and Sharma, E. (1994). Medicinal plants of the Sikkim Himalaya: Status, usage and potential. Bishen Singh Mahendra Pal Singh.

Rai, N. K., Tuli, L., Sarma, B. K., and Singh, U. P. (2000). Effect of plant extracts on spore germination of some fungi. Indian Journal of Plant Pathology, 18(1/2), 44-47.

Ramakrishnan, K., and Subramanian, C. V. (1952). The fungi of India a second supplement. Univ. Botany Laboratory.

Sahni, V. P. (1968). Deuteromycetes from Jabalpur. III. Mycopathologia etmycologiaapplicata, 36(3), 267-288.

Srivastava, D., and Singh, P. (2011). Antifungal Potential of Two Common Weeds Against Plant Pathogenic Fungi-sps. Alternaria. Asian J. Exp. Biol. Sci. 2(3): 525-528

Strange, R. N., and Scott, P. R. (2005). Plant disease: a threat to global food security. Annu. Rev. Phytopathol., 43, 83-116.

Vincent, J. M. (1947). Distortion of fungal hyphae in the presence of certain inhibitors. Nature, 159(4051), 850-850.

Yoon, M. Y., Cha, B., and Kim, J. C. (2013). Recent trends in studies on botanical fungicides in agriculture. The plant pathology journal, 29(1), 1.

\section{How to cite this article:}

Ranjana Juwantha, Akshit K. Lohan, Mohit Singh Bisht, Jalaj Saxena and Pooja Kapoor. 2021. Evaluation of Botanicals of Invasive Plant Species and Fungicides against Fungal Pathogens of Forest Nursery. Int.J.Curr.Microbiol.App.Sci. 10(09): 152-162.

doi: https://doi.org/10.20546/ijcmas.2021.1009.018 